\title{
Co-Endemicity of Plasmodium falciparum and HIV-Infections in Treated Patients is Uncorrelated in Benin City, Nigeria
}

Frederick, Olusegun Akinbo ${ }^{1}$, Richard Omoregie ${ }^{2}$, Luke Dixon ${ }^{3}$, Kyle Brown $^{3}$, Richard Wilson ${ }^{4}$, Mastanna Eraifej ${ }^{4}$, Sabrina Peoples $^{3}$, Adam Curtis $^{3}$, Skyler Battle ${ }^{3}$, Dymekea Bellamy ${ }^{3}$, Lea Shyneque ${ }^{3}$, Rocetia Robinson ${ }^{3}$, DC Ghislaine Mayer ${ }^{4}$, Johanna Marie Porter-Kelley ${ }^{3 *}$

${ }^{1}$ Department of Medical Laboratory Science, University of Benin, Benin City, Nigeria

${ }^{2}$ School of Medical Laboratory Sciences, University of Benin Teaching Hospital, Benin City, Nigeria

${ }^{3}$ Department of Life Sciences, Winston-Salem State University, Winston Salem, NC, USA

${ }^{4}$ Department of Biology, Manhattan College, Riverdale, NY, USA

\begin{abstract}
The Human immunodeficiency virus (HIV) and malaria are two of the world's most formidable pathogens. Coinfection has been shown to amplify the effects of both diseases with HIV infection enhancing the severity of malaria. Previous work in our laboratory has shown that individuals infected with malaria and HIV who are taking anti-retrovirals have the Plasmodium parasite in their bloodstream suggesting that the lack of anti-malarials in their drug regimen resulted in Plasmodium infection. In this study, we set out to determine the status of Plasmodium infection in a cohort of patients taking both anti-malarial and anti-retroviral drugs. Blood samples were collected from patients of the Edo district of Nigeria in Benin City co-infected with Plasmodium and HIV. We have found that 31 out of the $317(9.78 \%)$ HIV patients on HAART and ACT had Plasmodium in their blood based on microscopic counts. Surprisingly, using the polymerase chain reaction (PCR), the prevalence was at $25.6 \%$ for Plasmodium. In addition, we have identified by PCR that Plasmodium falciparum is the only species infecting these patients. Furthermore, no significant relationship was found to exist between $\mathrm{CD}^{+}{ }^{+} \mathrm{T}$-cell counts and malarial infections (CD4 count $<200$ cells $/ \mu \mathrm{L}(7.20 \%)$ ) nor was the malaria parasite density significantly associated with CD4 count $<200$ cells $/ \mu \mathrm{L}(P=0.595)$ in this study population in Benin City, Nigeria. These results suggest that other factors are involved in this complex interaction.
\end{abstract}

Keywords: Co-infection; Human immunodeficiency virus (HIV); Malaria; Plasmodium falciparum; Prevalence; Highly Active Antiretroviral Therapy (HAART); Artemisinin combinatorial therapy (ACT); CD4+ T-cells; Polymerase chain reaction (PCR)

\section{Introduction}

The human immunodeficiency virus (HIV) and Plasmodium species that infect human are responsible for two of the most prevalent and important infectious diseases on the planet. According to the World Health Organization (WHO), 219 million cases of malaria developed in the year 2010 alone and the $90 \%$ of these cases occur in sub-Saharan Africa where $67 \%$ of the world's HIV infections take place [1-3]. This has led to significant geographical intersection of the two diseases with a negative impact on both malaria and AIDS-related illnesses.

The immunosuppression caused by HIV infection has a negative effect on the immune response against the parasite leading to distinct disease outcomes between HIV-infected and HIV-uninfected individuals. At late stages of HIV infection or AIDS, the reduction of $\mathrm{CD} 4^{+} \mathrm{T}$-cells results in decreased $\mathrm{CD} 8^{+} \mathrm{T}$-cell counts and function, leading to severe alterations of the immune response against other pathogens, including Plasmodium [4,5]. HIV infection increases the risks of severe malaria and death from Plasmodium infection while malaria leads to increased illness in HIV-infected individuals under treatment [5]. Indeed, co-infection has been shown to increase HIV viral load 10 -fold in patients with malaria [6]. HIV infections have been associated with increased prevalence and severity of malaria causing severe morbidity in malaria patients in Ivory Coast $[7,8]$. This also occurs during pregnancy. Several studies have documented a higher Plasmodium parasitemia in HIV-infected pregnant women [9-11]. Likewise, Plasmodium infections were shown to cause a doubling of the HIV viral load in pregnant women $[12,13]$.

In previous surveys of HIV and malaria co-infections in Benin City, Nigeria, patients prescribed with HAART and ACT were excluded and a higher Plasmodium infection rate was observed in HIVinfected individuals [14]. Recently, Akinbo and Omoregie [15] have found a $2.11 \%$ prevalence of malaria, using microscopy techniques among 285 HIV-infected individuals taking HAART (zidovudine, stavudine, and nevirapine) and ACT (sulfadoxine, pyrimethamine, and dihydroartemisinine). Their study also reported a significant correlation between $\mathrm{CD} 4^{+} \mathrm{T}$-cell counts and malaria. In this study, we surveyed HIV and falciparum malaria co-infections, in Benin City, Nigeria, among patients prescribed with HAART (zidovudine, stavudine, and nevirapine) and ACT (artesunate-lumenfantrine combination) medications. We also took this study a step further to determine if Plasmodium falciparum was the only species present in these co-infected individuals.

\section{Materials and Methods}

\section{Study area}

The study was carried out at the University of Benin Teaching Hospital and Center for the United States President's Emergency Plan for AIDS Relief (PEPFAR) and according to Institute of Human Virology of Nigeria (IHVN) policy (PE, Benin City, Edo State, Nigeria. The teaching hospital is a tertiary health institution with a referral status serving 5 States of the Nigerian Federation: Edo, Delta, Ondo,

*Corresponding author: Johanna Porter-Kelley, Department of Life Sciences Winston-Salem State University, 601 Martin Luther King Dr. Winston Salem, NC 27110, USA, Tel: 336-750-3239; E-mail: porterkelleyj@wssu.edu

Received July 20, 2013; Accepted September 09, 2013; Published October 16, 2013

Citation: Akinbo FO, Omoregie R, Dixon L, Brown K, Wilson R, et al. (2013) CoEndemicity of Plasmodium falciparum and HIV-Infections in Treated Patients is Uncorrelated in Benin City, Nigeria. J Bacteriol Parasitol 4: 176. doi: 10.4172/21559597.1000176

Copyright: ( 2013 Akinbo FO, et al. This is an open-access article distributed under the terms of the Creative Commons Attribution License, which permits unrestricted use, distribution, and reproduction in any medium, provided the original author and source are credited. 
Anambra and Kogi. The study area is located in the Midwestern part of Nigeria and has an estimated population of 3.2 million people [16]. This study was conducted and samples were collected between February and late May of 2012.

\section{Study population}

The study population consisted of a total of 317 HIV-infected outpatients treated with HAART (zidovudine, stavudine, and nevirapine). One hundred and forty five males and 172 females, ranging from 20 to 68 years of age were selected. Patients with AIDS-defining conditions and those not on antiretroviral therapies were excluded from this study [17]. All HIV-infected patients were on a prophylactic ACT (artesunate-lumenfantrine combination) regimen and had no signs or symptoms of malaria.

\section{Ethical aspects}

Informed consent was obtained from all participants prior to specimen collection. The Ethical Committee of the University of Benin Teaching Hospital approved the protocol for this study.

\section{Specimen collection and processing}

Five milliliters of blood was collected from each participant, dispensed into an ethylene diamine tetra-acetic acid (EDTA) container, and mixed. A small sample of each blood sample was applied to Whatman ${ }^{\circledR}$ filter paper and allowed to dry.

\section{Parasite density}

Malaria was diagnosed using a method previously described in Akinbo et al. [15]. Briefly, thick blood films were made from each blood specimen and allowed to air-dry. The blood films were stained in a $3 \%$ Giemsa solution for 30 minutes, rinsed in tap-water, and allowed to airdry. A total of 200 fields per stained thick film were examined for malaria parasites by microscopy [18]. The parasite density was calculated from Giemsa-stained thick films by multiplying the ratio of the number of malaria parasite per 500 white blood cells by the assumed total white blood cell count of 4000 cells $/ \mu \mathrm{L}$ to give the malaria density in cells $/ \mu \mathrm{L}$.

\section{Quantitation of CD4 $4^{+}$T-lymphocytes}

The CD4 ${ }^{+}$T-lymphocyte count was evaluated using flow cytometry (Partec, Gmbh, Germany). Briefly, $20 \mu \mathrm{l}$ of CD4 PE antibody and $20 \mu \mathrm{l}$ of mixed whole EDTA blood were placed in Partec test tubes. The tube contents were mixed gently and incubated in the dark for 15 minutes at room temperature. This mixture was agitated during incubation every 5 minutes. To this mixture, $800 \mu \mathrm{l}$ of CD 4 buffer was added and mixed gently. The $\mathrm{CD} 4^{+} \mathrm{T}$-cells were then counted.

\section{DNA isolation}

Blood samples dried on Whatman ${ }^{\circledR}$ filter paper werepunched (3.0 $\mathrm{mm}$ in size) in triplicate from Whatman ${ }^{\circledR}$ filter paper blood smears. DNA was isolated from these punches at room temperature by incubating them in a high $\mathrm{pH}$ solution $(35 \mu \mathrm{l} 0.1 \mathrm{~N} \mathrm{NaOH}, 0.3 \mathrm{mM}$ EDTA, pH 13.0) for 5 minutes, followed by a neutral solution $(65 \mu \mathrm{l} 0.1$ $\mathrm{M}$ Tris- $\mathrm{HCl}, \mathrm{pH}$ 7.0) for 10 minutes [19].

\section{Polymerase chain reaction}

Polymerase chain reactions (PCR) were carried out in half reactions containing $2 \mu \mathrm{l}$ of extracted gDNA to which was added to 1 illustraTMpuReTaq Ready-To-Go PCR bead containing 2.5 units of puRetaq DNA polymerase, $400 \mu \mathrm{M}$ each of dATP, dGTP, dCTP, dTTP, 10
mMTrisHCl (pH 9.0), $50 \mathrm{mMKCl}$, and $1.5 \mathrm{mM} \mathrm{MgCl} 2$ (GE Healthcare, Buckinghamshire, UK), $2 \mu \mathrm{M}$ forward primer and $2 \mu \mathrm{M}$ reverse primer in nuclease-free water. The DNA was amplified using a forward primer specific to four of the five different species of Plasmodium known to infect humans (falciparum: 5 '-AAC AGA CGG GTA GTC ATG ATT GAG; vivax: $5{ }^{\prime}$-CGG CTT GGA AGT CCT TGT; ovale: $5{ }^{`}$-CTG TTC TTT GCA TTC CTT ATGC; and malariae: 5 '-CGT TAA GAA TAA ACG CCA AGCG) and a reverse primer conserved in all four of these Plasmodium species ( $5^{\circ}$-GTA TCT GAT CGT CTT CAC TCCC). The DNA was incubated at $95^{\circ} \mathrm{C}$ for 2 minutes, followed by 43 cycles each consisting of 45 seconds at $95^{\circ} \mathrm{C}, 90$ seconds at $60^{\circ} \mathrm{C}$ and 60 seconds at $72^{\circ} \mathrm{C}$, and a final step at $72^{\circ} \mathrm{C}$ for 5 minutes [20]. PCR products were analyzed by agarose gel electrophoresis. PCR products were visualized by ethidium bromide staining.

\section{Statistical analysis}

The parametric data were analyzed with student t-tests, while the non-parametric data were analyzed using a Chi-squared $\left(\chi^{2}\right)$ test and an odds ratio (OR) analysis, in the statistical software INSTAT ${ }^{\circledR}$ (GraphPad Software Inc, La Jolla, CA, USA) or an independent samples t-test in SPSS (IBM Corp, Armonk, NY).

\section{Results}

Previously, we assessed the prevalence of Plasmodium infections in HIV-infected patients prescribed HAART and a specific type of ACT formulation containing sulfadoxinepyrimethamine, and dihydroartemisinin (SPD), and those without HAART and antimalarials. We found a low prevalence of asymptomatic malaria among HIV patients on HAART and SPD compared to HIV-infected patients not receiving these therapies $[14,15]$. To verify the prevalence of malaria in HIV-infected patients prescribed HAART and a ACT treatment different from our previous study, artesunate-lumenfantrine combination therapy (ACT), we recruited $317 \mathrm{HIV}$-infected patients representative of the population in Benin City, Nigeria. These patients were grouped according to gender, age, and symptoms of AIDS (based on AIDS defining conditions) [15]. Among the recruited HIV-infected patients there were 145 males and 172 females ranging in age from 20 to 68 years. To ascertain malaria infections in our study population, thick blood smears were prepared and counted by light microscopy. The malaria parasite density ranged from $40-240$ parasites/ $\mu \mathrm{L}$ of blood (Table 1). The results of these counts showed that 31 out of the 317 (9.8\%) HIV patients prescribed HAART and ACT had malaria parasites in their blood (Table 1). To determine if the HIV infection status increased the prevalence of malaria in these patients, we determined the $\mathrm{CD} 4^{+} \mathrm{T}$-cell count of the patients by flow cytometry. The results showed that 40 out of 317 patients had CD4 $4^{+}$T-cell counts $<200$ cells/ $\mu \mathrm{L}(12.6 \%)$ and 277 out of 317 patients had $\mathrm{CD}^{+} \mathrm{T}$-cell of $\geq 200$ cells/ $\mu \mathrm{L}$ (87.4\%) (87.4\%)

\begin{tabular}{|c|c|c|c|c|c|}
\hline \multirow[t]{2}{*}{ Characteristic } & \multicolumn{2}{|c|}{ CD4 count (cells/ $\mu \mathrm{L})$} & \multirow[t]{2}{*}{ OR+ } & \multirow[t]{2}{*}{$95 \% \mathrm{Cl}^{*}$} & \multirow[t]{2}{*}{$p$ value } \\
\hline & $\leq 200$ & & & & \\
\hline \multicolumn{6}{|c|}{ Malaria parasite detection } \\
\hline Positive & $3(7.5 \%)$ & $28(10 \%)$ & 0.721 & $0.209,2.492$ & 0.815 \\
\hline Negative & $37(92.5 \%)$ & $249(89.9 \%)$ & & & \\
\hline Total & $40(12.6 \%)$ & $277(87.4 \%)$ & & & \\
\hline \multicolumn{6}{|l|}{ Malaria parasitemias } \\
\hline Density (parasite/ $\mu \mathrm{L}$ ) & 146.67 & 115.71 & & & 0.595 \\
\hline Standard Deviation & \pm 48.07 & \pm 11.14 & & & \\
\hline
\end{tabular}

Table 1: Prevalence of malaria in HIV-infected and non-infected individuals. 
(Table 1). These results suggest that a CD4 $4^{+} \mathrm{T}$-cell count of $<200$ cells/ $\mu \mathrm{L}$ was not significantly associated with asymptomatic malaria among HIV-infected patients prescribed HAART and ACT (7.2\%) when compared to those with $\mathrm{CD} 4^{+} \mathrm{T}$-cell count $\geq 200$ cells/ $\mu \mathrm{L}(10.1 \%)(\mathrm{OR}$ $0.72,95 \%$ CI: $0.21-2.49, p=0.82$ ) (Figure 1). The parasite density, though higher in HIV patients with CD4 count $<200$ cells/ $\mu \mathrm{L}(\mathrm{M}=146.67$, $\mathrm{SE}=48.1$ ), again was not significantly associated with asymptomatic malaria ( $p=0.60)$ (Figure 2). This observation is in accordance with our previously published report [15]

To identify the species of Plasmodium in our study cohort, PCR was conducted on 207 samples with primers specific for four of the five Plasmodium species known to infect humans, namely, falciparum, vivax, malariae, and ovale. We found a prevalence of $25.6 \%$ of $P$. falciparum (expected PCR product $300 \mathrm{bp}$ ) infection, while P. vivax, P. malariae, and $P$. ovale were not detected (Figure 3 and Table 2). This identifies the parasites in the blood of these patients prescribed ACT as P. falciparum and suggests that only $P$. falciparum is predominant in Benin City, Nigeria. In addition, data collected from the molecular study showed that the number of individuals in this study cohort infected with $P$. falciparum was much higher than that detected by microscopic counts. We did not test for P. knowlesi in this study.

\section{Discussion}

The brunt of the HIV pandemic has been borne disproportionately by resource-poor regions of the world, where tropical infectious diseases predominate [21]. P. falciparum, helminthes, and the HIV virus are endemic in sub-Saharan Africa making co-infection a reality. Akinbo et al have previously reported co-infections of $P$. falciparum and Ascaris lumbricoides in HIV-infected patients in Benin City, Nigeria [22]. In this study involving 2,000 HIV-infected patients that were examined from August 2007 to August 2009, we found that 25.2\% of the enrolled

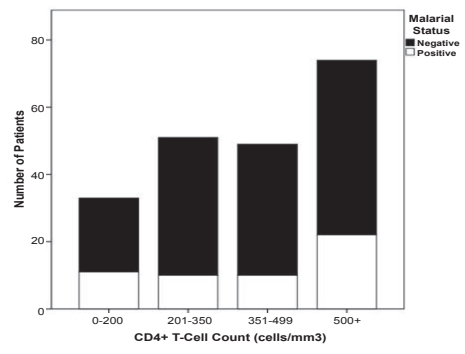

Figure 1: HIV disease status and malarial status is uncorrelated. Patients are grouped according to disease status (CD4+ T-Cell Count) and malarial status black (Plasmodium negative) and white (Plasmodium positive).

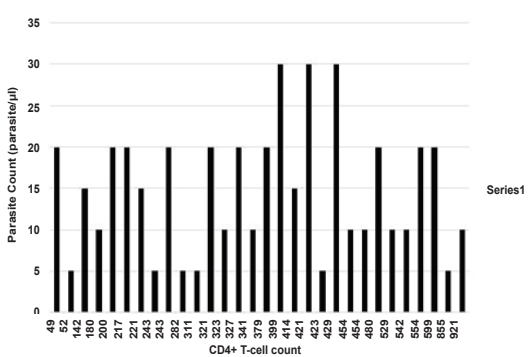

Figure 2: HIV disease status and parasite density are uncorrelated. Black vertical bars reflect parasite density of individual patients with corresponding CD4+ T-cell counts.

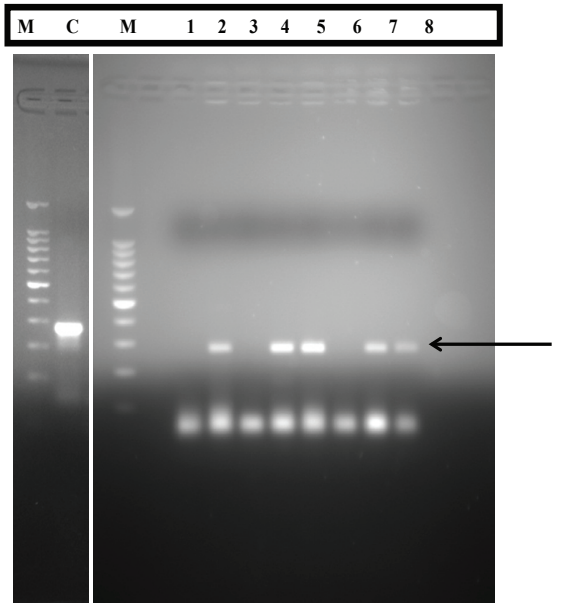

Figure 3: Ethidium bromide stained gel showing PCR products of P. falciparum amplified from patient blood. From left to right: 100 bp ladder (M), positive control PCR product (using P. fal DNA (gift from Dr. Rhoel Dinglasan)) (C), 100 bp ladder (M), and PCR products of eight different individuals (1-8). Lanes 2 , $4,5,7$, and 8 show expected PCR product of $300 \mathrm{bp}$ (arrow). Lanes 1, 3, and 6 did not show the expected PCR product.

individuals were positive for P. falciparum [15]. Among them, 34.4\% had a CD4 $4^{+} \mathrm{T}$ cell count of $<200$ and $10.1 \%$ had $\mathrm{CD} 4^{+} \mathrm{T}$-cell counts greater than 200, suggesting the P. falciparum infection was related to the $\mathrm{CD} 4^{+} \mathrm{T}$-cell counts. It is duly noted that patients who were on highly active antiretroviral therapy (HAART), antiparasitic agents, and those with AIDS-defining conditions were excluded from the study [15]. Another interesting finding was that none of the subjects tested showed co-infections with P. falciparum and intestinal parasitic infections other than in HIV-positive subjects. Thus, subjects with cell $<200$ cells $/ \mathrm{mm}^{3}$ showed an increased risk of opportunistic infections [15].

Furthermore, a low prevalence of $P$. falciparum infection among HIV-positive individuals undergoing treatment with HAART and sulfadoxine, pyrimethamine, and dihydroartemisinin was previously reported [15]. Patients on HAART with signs and symptoms of malaria and AIDS (by conditions) and those not on HAART were excluded from that study. In the same study, small subsets of these patients were observed to have asymptomatic malaria. The prevalence of anemia observed was $45.26 \%$ and is an important cause of anemia among HIV-infected patients on HAART [15]. Both HIV and Plasmodium infections can lead to anemia independently [21-23].

In this study, we examined the prevalence of Plasmodium infection in a cohort of HIV-infected individuals undergoing both HAART and ACT (artesunate-lumenfantrine combination) chemotherapies. By microscopic counts $9.8 \%$ HIV patients prescribed HAART and ACT had malaria parasites in their bloodstream (Table 1). By molecular studies the number of infections was much higher at a $25.6 \%$ prevalence of $P$. falciparum infection despite treatment with ACT (Table 2). The $\mathrm{CD} 4^{+} \mathrm{T}$-cell counts $<200$ cells $/ \mu \mathrm{l}$ was $12.6 \%$ (Table 1 ). However, there was no correlation between co-infection of HIV and Plasmodium. We asked whether there was a correlation between $\mathrm{CD} 4^{+} \mathrm{T}$-cell count and parasite density in the samples that tested positive for P. falciparum. In our analysis, we found no correlation between $\mathrm{CD} 4^{+} \mathrm{T}$-cells and the amount of parasites in these patients. A previous study done by Chavale et al. [24] showed that patients co-infected with HIV-1 and Plasmodium have a high amount of parasitemia and decreased $\mathrm{CD} 4^{+} \mathrm{T}$-cell count. Their results showed significantly lower $\mathrm{CD} 4^{+} \mathrm{T}$-cells values observed 
Citation: Akinbo FO, Omoregie R, Dixon L, Brown K, Wilson R, et al. (2013) Co-Endemicity of Plasmodium falciparum and HIV-Infections in Treated Patients is Uncorrelated in Benin City, Nigeria. J Bacteriol Parasitol 4: 176. doi: 10.4172/2155-9597.1000176

\begin{tabular}{|l|l|l|l|l|}
\hline Malaria status & Frequency & Percent & Valid Percent & $\begin{array}{l}\text { Cumulative } \\
\text { Percent }\end{array}$ \\
\hline Negative & 154 & 74.4 & 74.4 & 74.4 \\
\hline Positive & 53 & 25.6 & 25.6 & 100.0 \\
\hline Total & 207 & 100.0 & 100.0 & \\
\hline
\end{tabular}

Table 2: Malaria status using PCR.

in the P. falciparum/HIV (Pf/HIV) co-infected patients, which indicates a correlation between $\mathrm{CD} 4^{+} \mathrm{T}$-cell count and parasitemia. This finding does not agree with our study. A possible reason for this discrepancy is that the patients in Chavale's study were not taking either anti-retroviral or anti-malarial drugs. If both diseases are left untreated, symptoms worsen which explains the significant lower $\mathrm{CD} 4{ }^{+} \mathrm{T}$-cell count and high amount of parasitemia found in their studies.

Of the species of Plasmodium that were tested, only P. falciparum was found to be present in this cohort (Table 2 and Figure 3). This high prevalence of $P$. falciparum infection among this cohort of HIV-infected individuals subjected to HAART and ACT treatment may be due to either interference of the antiretrovirals on the antimalarial drugs or the action of the HIV virus, or that the parasite may be developing resistance to the ACT drugs. At the time of this study, resistance to ACT has not been reported in Nigeria. The lack of correlation with the CD4 ${ }^{+}$ T-cell count suggests that the virus is not implicated. $\mathrm{CD} 4^{+} \mathrm{T}$ cell counts in these patients suggest that the antiretroviral drugs are controlling the viral replication. The interference of antiretrovirals drugs with antimalarials has been suggested to occur [5]. Moreover, the treatment of HIV and malaria in co-infected patients create the potential for drug interactions with the potential for either increased drug toxicity or decreased concentration, which might lead to drug resistance. In addition to increasing malaria morbidity and mortality, HIV coinfection has been linked to increased antimalarial drug resistance [25]. We are actively investigating the mechanisms by which this interference occurs and the possibility of resistance that may have already developed in Nigeria. This is particularly important as $P$. falciparum isolates from Nigeria were shown to display increased susceptibility to artemether in vitro [26]. Another possibility is the stems from the observation that individuals living in malaria endemic regions have been known to have circulating parasites that the immune system controls. It is possible that the patients have circulating antibodies and possibly $\mathrm{CD} 8^{+} \mathrm{T}$-cells that are maintaining some control of the infection. This is another indication that would again point toward resistance to ACT in the Nigerian population. Our results have implications for the future treatment and prevention of malaria in HIV-infected individuals.

\section{Acknowledgments}

The authors are grateful to the Management of University of Benin Teaching Hospital for permission to carry out this study. The authors appreciate the Consultant Physicians of the Department of Internal Medicine of the University of Benin Teaching Hospital for their cooperation. We also thank the Winston-Salem State University, Department of Life Sciences, the American Society for Cell Biology Minority Affairs Committee (Linkage Fellowship) National Science Foundation HBCU-UP and the Department of Biology at Manhattan College for funding.

\section{References}

1. Patnaik P, Jere CS, Miller WC, Hoffman IF, Wirima J, et al. (2005) Effects of HIV1 serostatus, HIV-1 RNA concentration, and CD4 cell count on the incidence of malaria infection in a cohort of adults in rural Malawi. J Infect Dis 192: 984-991.

2. Steketee RW, Wirima JJ, Bloland PB, Chilima B, Mermin JH, et al. (1996) Impairment of a pregnant woman's acquired ability to limit Plasmodium falciparum by infection with human immunodeficiency virus type-1. Am J Trop Med Hyg 55: 42-49.

3. WHO (2005). World malaria report. WHO, Geneva, Switzerland.
4. Andreani G, Gagnon D, Lodge R, Tremblay MJ, Richard D (2012)An in vitro coinfection model to study Plasmodium falciparum-HIV-1 interactions in human primary monocyte-derived immune cells. J Vis Exp: e4166.

5. Flateau C, Le Loup G, Pialoux G (2011) Consequences of HIV infection on malaria and therapeutic implications: a systematic review. Lancet Infect Dis 11: $541-556$

6. Abu-Raddad LJ, Patnaik P, Kublin JG (2006) Dual infection with HIV and malaria fuels the spread of both diseases in sub-Saharan Africa. Science 314 1603-1606.

7. Berkley JA, Bejon P, Mwangi T, Gwer S, Maitland K, et al. (2009) HIV infection, malnutrition, and invasive bacterial infection among children with severe malaria. Clin Infect Dis 49: 336-343.

8. Davenport GC, Ouma C, Hittner JB, Were T, Ouma Y, et al. (2010) Hematologica predictors of increased severe anemia in Kenyan children coinfected with Plasmodium falciparum and HIV-1. Am J Hematol 85: 227-233.

9. Verhoeff FH, Brabin BJ, Hart CA, Chimsuku L, Kazembe P, et al. (1999) Increased prevalence of malaria in HIV-infected pregnant women and its implications for malaria control. Trop Med Int Health 4: 5-12.

10. van Eijk AM, Ayisi JG, ter Kuile FO, Misore A, Otieno JA, et al. (2001) Human immunodeficiency virus seropositivity and malaria as risk factors for thirdtrimester anemia in asymptomatic pregnant women in western Kenya. Am J Trop Med Hyg 65: 623-630.

11. van Eijk AM, Ayisi JG, ter Kuile FO, Misore AO, Otieno JA, et al. (2003) HIV increases the risk of malaria in women of all gravidities in Kisumu, Kenya. AIDS 17: 595-603.

12. Kapiga SH, Bang H, Spiegelman D, Msamanga GI, Coley J, et al. (2002) Correlates of plasma HIV-1 RNA viral load among HIV-1-seropositive women in Dar es Salaam, Tanzania. J Acquir Immune Defic Syndr 30: 316-323.

13. Ayisi JG, van Eijk AM, Newman RD, ter Kuile FO, Shi YP, et al. (2004) Materna malaria and perinatal HIV transmission, western Kenya. Emerg Infect Dis 10: 643-652.

14. Akinbo, FO, Okaka CE, Omoregie R, Mordi, R, Igbinuwen, O (2009) Prevalence of malaria and anaemia among HIV-infected patients in Benin City, Nigeria. NZ J Med Lab Science 63: 78-80.

15. Akinbo FO, Omoregie R (2012) Plasmodium falciparum infection in HIVinfected patients on highly active antiretroviral therapy (HAART) in Benin City, Nigeria. J Res Health Sci 12: 15-18.

16. Nigeria Masterweb (2006) Nigeria Edo State.

17. Center for Disease Control and Prevention (CDC) (2008) AIDS Defining Conditions. Morbidity and Mortality Weekly Report Recommendations 57 (RR10): 9 .

18. Omoregie R, Adedotun BB, Ogefere HO, Iduh P, Duru M (2007) Comparison of the efficacy of malaria PF rapid test device, Giemsa-stained thick blood film and QBC in the diagnosis of malaria in Benin City, Nigeria. Mary Slessor J Med 7: $1-4$.

19. Whatman, INC (2002) Whatman application note: Eluting genomic DNA from FTA $^{\circledR}$ cards using room temperature $\mathrm{pH}$ treatment.

20. Padley D, Moody AH, Chiodini PL, Saldanha J (2003) Use of a rapid, singleround, multiplex PCR to detect malarial parasites and identify the species present. Ann Trop Med Parasitol 97: 131-137.

21. Goselle ON, Onwuliri CO, Onwuliri VA (2009) Malaria infection in HIVIAIDS patients and its correlation with packed cell volume (PCV). J Vector Borne Dis 46: 205-211

22. Akinbo FO, Okaka CE, Omoregie $R$ (2012) Plasmodium falciparum and intestinal parasitic co-infections in HIV-infected patients in Benin City, Edo State, Nigeria. J Infect Dev Ctries 6: 430-435.

23. Karp CL, Auwaerter PG (2007) Coinfection with HIV and Tropical infectious diseases. I. Protozoal pathogens. Clin Infect Dis 45: 1208-1213.

24. Chavale H, Santos-Oliveira JR, Da-Cruz AM, Enosse S (2012) Enhanced T cell activation in Plasmodium falciparum malaria-infected human immunodeficiency virus-1 patients from Mozambique. Mem Inst Oswaldo Cruz 107: 985-992.

25. Kamya MR, Gasasira AF, Yeka A, Bakyaita N, Nsobya SL, et al. (2006) Effect 
Citation: Akinbo FO, Omoregie R, Dixon L, Brown K, Wilson R, et al. (2013) Co-Endemicity of Plasmodium falciparum and HIV-Infections in Treated Patients is Uncorrelated in Benin City, Nigeria. J Bacteriol Parasitol 4: 176. doi: 10.4172/2155-9597.1000176

Page 5 of 5

of HIV-1 infection on antimalarial treatment outcomes in Uganda: a populationbased study. J Infect Dis 193: 9-15.

26. Bustamante C, Folarin OA, Gbotosho GO, Batista CN, Mesquita EA, et al.
(2012) In vitro-reduced susceptibility to artemether in $P$. falciparum and its association with polymorphisms on transporter genes. J Infect Dis 206: 324332 